\title{
A Reform in Search of a Purpose: French Insolvency Law Changes (Again!)
}

\author{
by \\ Paul J. Omar \\ of Gray's Inn, Barrister
}

\section{Introduction}

In 1967, the roots of modern French insolvency law were laid down. ${ }^{1}$ The model was constituted, at its most basic, by a twin-track approach to insolvency, according to which a business could be sent down a rescue or a liquidation track (with the logical result) based on the situation in which the business found itself when it first appeared before the court. Under the supervision of an office-holder, named the syndic, a procedure would be instituted and would go through a number of phases before being finalised. The 1967 formulation was perhaps one of the earliest articulations of the concept of rescue, ${ }^{2}$ although Chapter 11 of the United States Bankruptcy Code is more famous and has been much admired and much emulated across the world. In essence, the 1967 model changed only a little in the way it was transformed in the 1980s, during a period in which many European jurisdictions re-examined their insolvency laws, although priority was to be given to rescue unless the business could quite clearly only be a candidate for liquidation. The 1980s' articulation of insolvency consisted of 3 separate laws, introducing (for the first time) a pre-insolvency and diagnostics process as well as the regulation of office-holders alongside the twin-track system by then hallowed in usage. $^{3}$ The system as maintained by the Laws of 1984-1985 lasted in essence till the mid-2000s, albeit with some changes in nomenclature and personnel. There was, nonetheless, some slight recalibration of the balance between creditors' and debtors' rights and a few procedural changes that intervened in the mid-1990s. ${ }^{4}$ There was subsequently the reconsolidation of insolvency laws, along with many other commercial texts, in a new and reinvigorated Commercial Code in 2000 as part of the bicentenary celebrations of the great codification project inaugurated by Napoleon. ${ }^{5}$

In the period following the millennium though, there was a flurry of activity centred on the commercial law arena. The reason largely stemmed from investigations carried out by Parliamentary and Justice Ministry investigators into the functioning of the commercial courts in the course of 1998-1999,

\footnotetext{
1 Law no. 67-563 of 13 July 1967.

2 Although the rescue imperative it contains may be traced back to an earlier embryonic formulation in a Decree-Law of 20 July 1955.

${ }^{3}$ Law no. 84-148 of 1 March 1984 (pre-insolvency and diagnostics) ("Law of 1984"), Law no. 85-98 of 25 January 1985 (insolvency law) (“Law of 1985”) and Law no. 85-99 of 25 January 1985 (regulation of office-holders).

${ }^{4}$ Law no. $94-475$ of 10 June 1994. An outline of the post-1994 structure of French law can be found in A. Sorensen and P. Omar, Corporate Rescue Procedures in France (1996, Kluwer, Deventer).

${ }^{5}$ In the Commercial Code, pre-insolvency, diagnostics and insolvency law together form Book $\mathrm{VI}$, while the regulation of office-holders is to be found in Book VIII.
} 
which led to the discovery of instances of malfunction, misfeasance as well as behaviour ranging from the unethical to the criminal, which led in certain cases to prosecutions. The Government's response was to set out an agenda in 1999 in a Preparatory Orientation Document, which discussed possible reforms to insolvency law, the regulation of insolvency practitioners and the framework for the functioning of commercial justice. Opposition from within the judicial milieu and professions succeeded in derailing some of the commercial court reforms, but insolvency practice was the subject of an overhaul in 2003, while insolvency law reforms reached the statute book in $2005 .{ }^{6}$ The Law of 2005 introduced a new procedure called sauvegarde (preservation), designed by analogy with the existing rescue procedure, but set further upstream so that it would be of benefit for possible early intervention in the life of a failing company. Adjustments were made to the functioning of pre-insolvency processes, extending their availability even to technically insolvent debtors, while the liquidation process was the subject of measures designed to speed it up. All in all, the insolvency framework as a result of the Law of 2005 looked to be as modern a system as it was possible to get and one that would survive the challenges of an ever-fluctuating economic environment in Europe and in which France saw itself as a key player.

The early promise, represented by the changes brought in by the Law of 2005, did not last. All too soon, the Government noted the lack of take up for the new sauvegarde procedure, with just over 500 procedures being opened in each of the first few years after the Law of 2005 came into force. ${ }^{7}$ Although the limited statistics may not be entirely significant, comparisons were made to the relative take up of conciliation and ad hoc mandates, where some 2500 procedures were reported annually, an increase from 1500 procedures before the entry of the law into force. ${ }^{8}$ Nevertheless, rescue procedures overall seemed not to fare well, while liquidations continued to soar. This prompted the changes that intervened in 2008, when Article 74 of the Law of $2008^{9}$ was used to authorise the French Government to rely on the exceptional powers in Article 38 of the Constitution to legislate by way of ordinance in order to reform the insolvency law framework. ${ }^{10}$ The Ordinance of 2008 made major changes affecting all of the insolvency procedures contained within Book VI of the Commercial Code, notably by increasing the options open to entrepreneurs faced with financial difficulties as well as enhancing the

\footnotetext{
${ }^{6}$ Law no. $2005-845$ of 26 July 2005 ("Law of 2005"). An account of the process leading up to the adoption of this law can be found in P. Omar, The Progress of Reforms to Insolvency Law and Practice in France, Chapter 3 in K. Broc and R. Parry (eds.), Corporate Rescue in Europe: Recent Developments (2004, Kluwer, Deventer), at 51-78; updated in P. Omar, Reforms to the Framework of Insolvency Law and Practice in France: 1996-2006, Chapter 6 in K. Broc and R. Parry (eds.), Corporate Rescue: An Overview of Recent Developments (2 ${ }^{\text {nd }}$ ed) (2006, Kluwer, Deventer), at 111-150.

7 See T. Montéran, Pour améliorer le droit des entreprises, osons la réforme, Gazette du Palais 24 January 2008, no. 24, at 3 . More precise statistics are quoted by $\mathrm{M}-\mathrm{H}$. MonsèriéBon and C. Saint-Alary-Houin, La loi des sauvegarde des entreprises: nécessité et intérêt d'une réforme annoncée, Recueil Dalloz 2008, at 941, noting 500 procedures in 2006 and 506 in 2007.

${ }^{8}$ Montéran, above note 7 , at 3.

${ }^{9}$ Law no. 2008-676 of 4 August 2008 on the Modernisation of the Economy ("Law of 2008").

10 This procedure was also used for the consolidation in 2000 of texts into a revived Commercial Code.
} 
operation of the various insolvency procedures, especially those that favoured negotiations with the creditors and supported upstream rescue. As such, the bulk of its provisions addressed the perceived deficiencies in the law on sauvegarde. ${ }^{11}$ It was also accompanied by a report addressed to the President of the Republic and was later completed by regulations introduced by decree, ${ }^{12}$ which also modified the regulatory sections of the Commercial Code and incidentally altered the conditions for the seizure and sale of properties.

In the wake of the global financial crisis, developments in practice prompted further reforms in 2010 to introduce the pre-pack via a new procedure called sauvegarde financière accélérée (accelerated financial preservation). Designed as a variation on the sauvegarde procedure, the new procedure resulted from a package of reforms to the banking and financial sectors contained in an omnibus text. ${ }^{13}$ The new procedure was designed for the use of debtors who had been undergoing a conciliation procedure, but who could also demonstrate the criterion for entry to sauvegarde and who would, because of their size, be required to have creditors' committees formed for the purposes of approving a rescue plan. ${ }^{14}$ These debtors could apply to court with a plan in hand they believed would assure the continuation of the business and that could command the support of a majority of financial creditors and/or bondholders. ${ }^{15}$ The court would take into account the views of the conciliator on the progress of conciliation and the likelihood of adoption of the draft plan by the relevant creditors/bondholders. ${ }^{16}$ Once approval had been obtained, the court would adopt the plan, normally within a month of proceedings being opened. If approval was not forthcoming, the procedure would be terminated. ${ }^{17}$

\section{First Steps towards Reform}

With the cumulative reforms and the introduction of new insolvency tools represented by the Law of 2005, Ordinance of 2008 and Law of $2010,{ }^{18}$ it appeared as if the French insolvency law framework had the necessary range of procedures to enable rescue to be attempted, whether upstream or after insolvency and whether light-touch or more formal in nature. However, the continued impact of the global financial crisis, the impact of the Eurozone crisis, concerns about the continued viability of French businesses, chronic underemployment and the seeming inability of successive administrations to

\footnotetext{
11 Ordinance no. 2008-1345 of 18 December 2008 (“Ordinance of 2008”). An account of these reforms can be found in P. Omar, French Insolvency Law: Remodelling the Reforms of 2005 [2009] 6 ICCLR 225; P. Omar, Preservation and Pre-Packs à la Française: The Evolution of French Insolvency Law after 2005 [2011] 8 ICCLR 258, the latter also dealing with the 2010 developments.

12 Decree no. 2009-160 of 12 February 2009.

${ }_{13}$ Articles 57-58, Law no. 2010-1249 of 22 October 2010 ("Law of 2010").

${ }^{14}$ Articles L. 620-1 and L. 626-29, Commercial Code.

15 Ibid., Article L. 628-1.

16 Ibid., Article L. 628-2.

17 Ibid., Article L. 628-6.

18 A further Law no. 2010-1512 of 9 December 2010 was also passed to adapt the law of insolvency to "one-man" companies.
} 
turn the economy around were all factors that prompted a review of insolvency law by the Government that was elected in $2012 .{ }^{19}$ For one commentator, the enactment of a new text was not surprising as law-making remained the only tool available to a Government, whose "monetary, customs, financial, tax and political margin of manoeuvre [was] non-existent or largely reduced". ${ }^{20}$ The report that accompanied the text itself referred to the Government's presentation in November 2012 of a National Agreement for Growth, Competitiveness and Employment which, while not seeking to undermine the broad orientation of the insolvency law framework, was geared to improving its workings. ${ }^{21}$ The Presidential Report stated the principal objectives of the text as being to facilitate the anticipation of worsening economic conditions by businesses, to reinforce the efficiency of procedures by adjusting the impact of creditors, debtors and others, to adapt to the prevailing reality the treatment of businesses in an irremediable and compromised situation (situation irrémediablement compromise) while respecting the relative rights of creditors and debtors as well as to improve procedural rules to ensure "greater security, simplicity and effectiveness".

The first draft of what would become the Ordinance of $2014^{22}$ was published in December 2013 for the purposes of a public consultation. It reflected the themes later set out in the Presidential Report, although the work leading to the draft had begun with a questionnaire sent out by the Ministry of Justice in December 2012 and the setting up of a committee in March 2013 to examine reforms that would improve matters, albeit preserve the broad thrust of the insolvency law framework. The procedure for enacting the text was that also chosen for the 2008 reforms with authority being given to the Government by virtue of a law passed in early 2014 whose general objective was to simplify and provide security for business life. ${ }^{23}$ The law required the Government to proceed to the adoption of an ordinance within the parameters it set out. ${ }^{24}$ These were quite extensive, including the need to improve the workings of prevention measures in two ways, by opening up their scope of application and improving the mechanisms for alerts by auditors as well as by a range of measures, such as enabling judges to extend payment periods, avoiding contractual clauses preventing recourse to the procedure, improving creditors' rights in the context of the quest for a compromise/settlement with the debtor and a better framework for procedural costs and expenses of specialists and external parties. ${ }^{25}$ Further considerations included the need to improve access to post-insolvency financing and security rights, while avoiding an adverse impact on employment rights, and the need to reinforce the effectiveness of

\footnotetext{
19 See P. Pétel, Entreprises en Difficulté: encore une réforme! La Semaine Juridique Entreprises et Affaires No. 18 (1 May 2014), at 20 (paragraph 1); P-M Le Corre, Premiers regards sur l'ordonnance du 12 mars 2014 réformant le droit des entreprises en difficulté, Recueil Dalloz 2014, at 733 (paragraph 2).

20 Pétel, above note 19, at 20 (paragraph 1).

${ }^{21}$ Rapport au Président de la République relative à l'ordonnance no. 2014-326 du 12 mars 2014 portant réforme de la prévention des difficultés des entreprises et des procédures collectives ("Presidential Report"), in the Introduction.

22 Ordinance no. 2014-326 of 12 March 2014 ("Ordinance of 2014").

${ }^{23}$ Law no. 2014-1 of 2 January 2014 ("Law of 2014").

24 lbid., Article 2.

${ }^{25}$ Idem, paragraph 1.
} 
the sauvegarde procedure through facilitating access to the procedure and the creation of a variant of the procedure for use in cases where prior conciliation proceedings had failed. ${ }^{26}$

In the case of the more formal collective procedures, concerns to be reflected in the text included the need to achieve a better solution allowing for the continuation of business and associated employment by balancing the relative rights of participants in the process, including through re-examining information rights given to creditors and employees as well as shareholder rights in restructurings. ${ }^{27}$ For businesses that had ceased paying creditors and thus fell within the scope of formal proceedings, the law set out the requirement to find a special solution for failed businesses without major assets or employees that would balance the procedural costs (of realising assets) against the need to close down procedures early and discharge debtors. ${ }^{28}$ Also of interest in the reforms were improvements to liquidation procedures, to be achieved through improving the asset-sale process and allowing for procedures to be closed down where debts had been settled or the assets were insufficient to meet the overall debt. ${ }^{29}$ Concerns were also voiced about the situation of businesses subject to collective insolvency procedures, where business activity had ceased, and the position of their employees, to be met by harmonising the provisions of the Commercial and Employment Codes.30 Sundry thought was also given to the judicial administration of procedures, to be improved by further defining the role of the court itself, in suo sponte procedures, as well as those of the supervising judge and prosecutors. ${ }^{31}$ Improving judicial access to information and their ability to take into account the wider context of insolvency procedures by considering the interests of stakeholders was also a factor here. ${ }^{32}$ Further amendments would improve the administration of procedures generally by speeding up the process for proving debts and specifically by allowing for procedures to be transferred to other courts for procedural efficiency where debtor companies were related through group structures. ${ }^{33}$ The resulting text is quite extensive and weighty, with 117 articles effecting changes, not just to the insolvency provisions in the Commercial Code, but to provisions scattered across a range of other texts. The amendments both create new procedures as well as changes to the operation of existing procedures.

\section{The Invention of New Procedures}

Two new procedures have been created as part of the 2014 reforms: a variant on the sauvegarde procedure called the sauvegarde financière (financial preservation) and a procedure to deal with impecunious estates called the rétablissement professionnel (professional re-establishment). Both procedures may fairly be described as "dependent" in that their coming into existence

\footnotetext{
26 Idem, paragraphs 2-3.

27 Idem, paragraph 4.

28 Idem, paragraph 5.

29 Idem, paragraph 6.

30 Idem, paragraph 8.

31 Idem, paragraph 7(c)-(d), (f).

32 Idem, paragraph 7(b).

${ }^{33}$ Idem, paragraph 7(a), (e).
} 
depends on a prior procedure being engaged, in the first instance conciliation proceedings being afoot, while in the second, there being a demand for the opening of liquidation proceedings.

\section{(a) Sauvegarde Financière (Financial Preservation)}

The section in the Commercial Code dealing with the sauvegarde financière accélérée has been rewritten to introduce the new sauvegarde financière, of which the procedure introduced in 2010 will be a subset. The new procedure will be available to debtors who have been engaged in a conciliation procedure who can demonstrate that they have drafted a plan that is likely to result in the continuation of business. For that reason, particular rules ordinarily applicable to sauvegardes on the breaking of contracts and permitting creditors to recover property subject to quasi-security and other rights are not applicable. The draft plan must also be likely to meet with the approval of those creditors, whom the opening of the procedure is intended to affect, within the timeframe set out by the law. The procedure can only be opened in respect of a debtor who meets two conditions: (i) its accounts are audited or certified by an accountant and overall the size of the business is over the thresholds to be fixed by decree; and, in the case of group companies, (ii) the business has consolidated accounts as required by law. As the procedure depends on a prior conciliation existing, the fact that the debtor is in a formal state of insolvency does not prevent the opening of proceedings as long as the debtor became insolvent within 45 days prior to the conciliation application being made. ${ }^{34}$ If in fact the debtor became formally insolvent before this grace period, the Public Prosecutor has the right to ask the court to bring the procedure to an end. ${ }^{35}$

The decision to open proceedings is taken by the court on the basis of a report prepared by the conciliator expressing an opinion on the likelihood of the plan being adopted by the creditors concerned. The court is given a right of access to any information available in the course of the prior conciliation proceedings and any ad hoc mandates that might have been carried out. The decision is examined in the presence of the Public Prosecutor. ${ }^{36}$ If the application is successful, then the court will appoint one or more administrators to be in charge of the procedure. If the conciliator belongs to one of the two insolvency professions, he may be appointed to the role commonly exercised by the relevant profession in insolvency proceedings (i.e. as either administrator or judicial nominee). If the court thinks fit, it may give reasons supporting its choice to appoint another person to supervise the procedure. At the same time, the debtor may be dispensed from having to establish the asset inventory commonly required in the process. ${ }^{37}$ For companies that are normally not required to set up creditor committees (because they fall under the specified threshold), the court will nevertheless order that committees be summoned to consider the plan. ${ }^{38}$ The opening of

\footnotetext{
34 Article L. 628-1 (new), Commercial Code, inserted by Article 48, Ordinance of 2014.

35 lbid., Article L. 628-5 (new).

${ }^{36} \mathrm{lbid}$., Article L. 628-2 (new).

37 Ibid., Article L. 628-3 (new).

38 Ibid., Article L. 628-4 (new).
} 
proceedings is deemed to affect those creditors who are normally required to file proofs of debt as well as any contracting parties. ${ }^{39}$ To that end, the debtor is required to file in court a list of known creditors and the amounts owing them as certified by an auditor or accountant. The amount of the debt owing in respect of each creditor is also notified to creditors by the judicial nominee. If the creditors do not subsequently file a proof of debt, then the amounts filed by the debtor will stand. In certain conditions, the list of debts may be updated. ${ }^{40}$

Once approval has been obtained from the relevant creditors/bondholders, the court will approve the adoption of the plan. This will normally have to occur within a period of 3 (three) months from the date proceedings are opened. If the court does not do so within this period, then proceedings are automatically vacated. Where plans are adopted, the rules normally applicable to minimum repayments and maximum rescheduling periods do not apply. ${ }^{41}$ If in the examination of the debtor's accounts, it appears that the only creditors likely to be affected by the adoption of a plan will be financial institutions and/or bondholders, then a sauvegarde financière accélérée may be opened which will only have effect on those creditors, provided they approve the plan. ${ }^{42}$ The approval process is reduced from 15 (fifteen) to 8 (eight) days, while the period within the court must adopt the plan is similarly truncated to 1 (one) month, with the possibility of a limited extension for a similar period. ${ }^{43}$

Overall, the procedure presents some differences from an ordinary sauvegarde. It cannot be converted into any other procedure, i.e. the failure to adopt a plan or to continue to qualify (by not being in cessation of payments) brings the process to an end. It only has effect on the creditors involved, in the case of the sauvegarde financière accélérée, the financial institutions and/or bondholders, while in the main sauvegarde financière, employees are not intended to be affected. Furthermore, the court cannot impose any minimum repayment terms, but must leave the procedure to be governed ultimately by the plan the creditors have approved, albeit the law simplifies the process in some important respects. Provided that the accounts on the basis of which the plan has been drafted have been certified (thus protecting the creditors) and that the hearing takes place in the presence of the Public Prosecutor (representing the public interest), then the matter is uniquely one for the debtor and relevant creditors. This explains why the court must be convinced that the plan is likely to have their approval, a fact that can be supported by the participation of the conciliator from the precursor procedure. ${ }^{44}$

Although the sauvegarde financière accélérée has been rightly termed "semicollective", 45 the sauvegarde financière itself contains a cram-down element achieved by the adoption of the plan by the court following approval by the

\footnotetext{
39 Ibid., Article L. 628-6 (new).

40 lbid., Article L. 628-7 (new).

41 lbid., Article L. 628-8 (new).

42 lbid., Article L. 628-9 (new).

43 Ibid., Article L. 628-10 (new).

44 Parliamentary Report, at paragraph I-3.

45 See P. Rossi et al., Réforme du droit des entreprises en difficulté (Bulletin no. 358-1) (April 2014) (Special issue of the Dictionnaire Permanent: Difficultés des entreprises), at 9.
} 
creditors in respect of whom it applies. Moreover, the advantages of the sauvegarde financière, particularly its speed, are stated as being efficiency in terms of not losing business value, the fact that it does not affect the workforce and that the plan represents the fruits of a negotiation between the debtor and the principal creditors. ${ }^{46}$ The last item is perhaps particularly important given that the success (or not) of the plan will reply largely on the continued goodwill of the creditors called upon to make it work. Just like the sauvegarde financière accélérée, which was said to be particularly useful because it could serve as a form of pressure on recalcitrant creditors as well as provide a useful way out of conciliation proceedings that might be paralysed by a minority, ${ }^{47}$ the sauvegarde financière, as it has been created, might well serve a similar purpose.

(b) Rétablissement Professionnel (Professional Re-establishment)

This procedure is sited in the context of an application for liquidation. It is intended to reflect the prevailing reality in an increasing number of cases and is based on an equivalent procedure applicable to asset-less instances of surendettement des particuliers (consumer over-indebtedness). ${ }^{48}$ The opening of proceedings is subordinated to a considerable number of conditions being fulfilled: (i) the debtor is a personne physique (individual); (ii) the debtor is not subject to any insolvency proceedings; (iii) the debtor has had no employees within the six months prior to an application being made; (iv) the assets of the business are less than an amount to be fixed by decree; (v) the debtor's assets have not been divided into personal and business portions (as would be the case with a sole entrepreneur enjoying limited liability); (vi) no proceedings before the Conseil de Prud'hommes (Employment Tribunal) affecting the debtor are pending;49 (vii) no liquidation or professional re-establishment proceedings have been closed down (in the case of the liquidation, by reason of a lack of assets) in respect of his business or personal assets within the past 5 (five) years. ${ }^{50}$ An application for the opening of liquidation proceedings may also include one for the opening of a professional re-establishment procedure. A court may not agree to the request unless the pre-conditions are met and the opinion of the Public Prosecutor has been sought. ${ }^{51}$ The procedure is open for a maximum of 4 (four) months and is run by a juge commis (commissary judge), whose task will be to collect all necessary information on the debtor's property, including asset values and the amount of any liabilities. The commissary judge may be assisted by a judicial nominee appointed for that purpose. ${ }^{52}$ The commissary judge enjoys all the powers available to a supervisory judge in the context of sauvegardes and may communicate any information and documents to the judicial nominee that would be useful for his mission. ${ }^{53}$

\footnotetext{
46 Idem.

47 Pétel, above note 19, at paragraph 12.

48 Presidential Report, at paragraph III-1.

49 Article L. 645-1 (new), Commercial Code, inserted by Article 85, Ordinance of 2014. Article

57 , Ordinance of 2014 , also amends the chapter heading to include the new procedure.

50 Ibid., Article L. 645-2 (new).

51 lbid., Article L. 645-3 (new).

52 lbid., Article L. 645-4 (new).

53 lbid., Article L. 645-5 (new).
} 
The procedure carries a limited moratorium in that the commissary judge may, at the debtor's request, postpone the payment of any sums due for the period of up to 4 (four) months. The commissary judge may similarly suspend any enforcement of judgments already obtained. Any contractual term stating that the opening of proceedings does not affect the creditor's rights to take or enforce proceedings is deemed void. ${ }^{54}$ The role of the judicial nominee is essentially to act to preserve the debtor's rights in relation to property and to report to the commissary judge any actions taken in this respect. ${ }^{55}$ Otherwise, his main function is to liaise with the creditors and to obtain from them information with respect to sums owed and when these are due, together with any other claims they may have over the debtor's property. ${ }^{56}$ The procedure may be brought to an end prematurely and a liquidation substituted if the debtor is shown to have acted in bad faith or has breached any rule in respect of the moratorium on payments or carried out a transaction vulnerable to a claw-back action or which might attract one of the sanctions provided in Title V. The same will apply if one of the pre-conditions is found subsequently not to have been met or that circumstances have changed since the order was made meaning that any one of the pre-conditions is no longer met.

A request to bring the procedure to an end may be brought by the Public Prosecutor or any of the creditors. In addition, in respect of a failure to meet any of the pre-conditions, the debtor may also petition the court. ${ }^{57}$ The end of the procedure, whether naturally or prematurely, may only occur by the commissary judge sending the matter to the whole court for decision following receipt of a report from the judicial nominee and an opinion being given by the Public Prosecutor. There is a limited right of appeal against the decision. ${ }^{58}$ Where the procedure ends naturally, all debts arising prior to the opening of proceedings are extinguished, the only exceptions being debts owing to employees, alimony and subsistence, criminal penalties as well as claims for contributions made by guarantors. ${ }^{59}$ Where the debtor is subsequently found to have had the benefit of a procedure by failing to declare completely the amount of his assets or liabilities, a court hearing an application for the opening of liquidation proceedings may order the restoration of the rights of creditors whose debts were extinguished and dispense them from having to prove those debts in subsequent proceedings. ${ }^{60}$

The rationale for the tight control over the procedure evident in its restrictive provisions is so as to avoid the risk of abuse. ${ }^{61}$ Statistics are cited that show such a procedure would, nonetheless, be extremely useful, with up to a third of all liquidations currently opened in fact involving no employees whatsoever and limited assets. The idea is to facilitate the debtor returning to some form of activity, perhaps even entrepreneurial, following his debts for the most part

\footnotetext{
54 Ibid., Article L. 645-6 (new).

55 Ibid., Article L. 645-7 (new).

56 lbid., Article L. 645-8 (new).

57 lbid., Article L. 645-9 (new).

58 lbid., Article L. 645-10 (new).

59 lbid., Article L. 645-11 (new).

60 lbid., Article L. 645-12 (new).

${ }^{61}$ Presidential Report, at paragraph III-1.
} 
being extinguished in a fast procedure that is not designed to function like other, more collective procedures. ${ }^{62}$ For some commentators, one advantage of the existence of this new procedure is that it would not be seen as a true insolvency procedure, thus improving the relative statistics for rescues and liquidations. ${ }^{63}$ In fact, in some countries, such procedures simply occur by administrative or judicial fiat and are not counted as insolvency proceedings. Although acknowledged by one commentator as still representing in effect a failure, the exclusion of this procedure from the statistics would do much to improve France's standing in insolvency terms, especially in view of the competition between insolvency systems. ${ }^{64}$

\section{Changes to Existing Procedures}

For the most part, the vast number of amendments contained in the Ordinance of 2014 make extensive changes to the insolvency provisions of the Commercial Code and affect all of the areas into which Book VI on insolvency is divided. The most important of these are dealt with in the order that the procedures appear in the main text.

\section{(a) Prevention and Conciliation}

In terms of prevention, the scope of the law is extended to cover noncommercial incorporations and agricultural or other professional activity to allow for court involvement in summoning the managers/directors/partners in these businesses for questioning as to the prospects of the business. For these purposes, the President of the Tribunal de Grande Instance (the equivalent to the High Court) has competence in the same terms as the President of the Commercial Court would, excepting where lawyers, insolvency practitioners or public office-holders are concerned. In this instance, reference has to be made to the relevant professional supervisory authority to report any economic, financial or business problems of which the court has been apprised. ${ }^{65}$ Where intervention by the court leads to the appointment of a mandataire ad hoc (ad hoc nominee), the auditor of the business is also informed. ${ }^{66}$ The intention here is to keep the auditor, who has a right to inform the court in any event, informed of the progress of any turnaround activity.

As far as the conciliation procedure is concerned, a little tidying up clarifies that the court's order opening conciliation may prescribe a period of up to 4 (four) months, but may extend this, provided the extension does not take the overall period to more than 5 (five) months. The conciliator appointed may also seek information, despite any confidentiality rules to the contrary, from a

62 See P. Roussel Galle, Le rétablissement professionnel: de l'effacement des dettes au rebond, Gazette du Palais (23 April 2014), no. 98, at 32, citing F-X. Lucas and M. Sénéchal, la procédure d'enquête pour le rétablissement professionnel, Recueil Dalloz 2013, at 1852. These suggest there may be up to 20,000 insolvencies annually not involving any employees for whom this procedure would be ideal.

63 Idem; Pétel, above note 19, at paragraph 20.

${ }^{64}$ Roussel Galle, above note 62, at 34 .

${ }^{65}$ Article L. 611-2-1 (new), Commercial Code, inserted by Article 2, Ordinance of 2014.

${ }^{66}$ Article L. 611-3 (modified), Commercial Code, amended by Article 3, Ordinance of 2014. 
wider range of public and private organisations than hitherto prescribed ${ }^{67} \mathrm{~A}$ real novelty in this section, especially noted by commentators, ${ }^{68}$ is the extension of a power for the conciliator to proceed to a sale of the going concern, whether in whole or in part. The sale can also take place in any subsequent procedure that is opened, including sauvegarde, judicial rescue or liquidation. ${ }^{69}$ This is described as quite a "spectacular innovation that opens a further route to exit from conciliation". Although such sales could take place with the debtor's consent and concurrence of major creditors, the advantage of this change is that the power can be exercised in subsequent procedures, leaving the quest for a purchaser to take place in the relative privacy of the conciliation process and the transfer to receive the sanction of a court in other proceedings, ${ }^{70}$ as is the case with the prepack process in some other countries, including the United Kingdom.

As further improvements to conciliation, the existing facility to suspend payments and reschedule debts is to be subordinated to the conclusion of an agreement. ${ }^{71}$ Restoring the pre-2008 position, where an agreement is reached, debts that it does not cover may be made subject to the same facility. ${ }^{72}$ Although this does not quite resemble the "cram-down" effect in voluntary arrangements, it does represent a welcome return to the prior position as hitherto the agreement could only have an impact on creditors who had agreed to it, underlining its consensual nature. In either case, the facility is subject to the views of the conciliator or supervisor, respectively. In fact the position of supervisor, which exists in other procedures for the purposes of overseeing the implementation of any rescue plan, is a novelty here. With the aim of providing some continuity, the debtor is now allowed to ask the court to appoint the conciliator as a supervisor to oversee the implementation of the agreement for its entire duration. ${ }^{73}$ Also of interest to employees is a new right of information about the contents of any agreement where the debtor makes application for its adoption by the court. ${ }^{74}$ The remuneration of both conciliators and plan supervisors is the subject of an amended provision that requires the court to determine how the amounts are to be calculated at the time of their appointment. A specific prohibition is included preventing remuneration being calculated in function of debt waivers or a flat fee being charged. ${ }^{75}$ Finally in this section, improving access to conciliation and other preventive measures is a provision that renders void any contractual term purporting to alter contract rights, whether reducing the debtor's rights or

\footnotetext{
${ }^{67}$ Article L. 611-6 (modified), Commercial Code, amended by Article 4, Ordinance of 2014.

68 See P. Roussel Galle, La réforme du droit des entreprises en difficulté par l'ordonnance du 12 mars 2014, Revue des Sociétés (June 2014), at 355 (paragraph 18).

69 Article L. 611-7 (modified), Commercial Code, amended by Article 5, Ordinance of 2014. Article L. 642-2 (modified), Commercial Code has also been amended by Article 70, Ordinance of 2014, to allow for any plans formulated by the ad hoc nominee or conciliator to be implemented in the context of a subsequent liquidation. This is subject to the Public Prosecutor having expressed a view.

70 Roussel Galle, above note 68, at 355 (paragraph 18).

${ }^{71}$ Article L. 611-7 (modified), Commercial Code, amended by Article 5, Ordinance of 2014.

72 Article L. 611-10-1 (modified), Commercial Code, amended by Article 8, Ordinance of 2014.

${ }^{73}$ Article L. 611-8 (new paragraph), Commercial Code, amended by Article 6, Ordinance of 2014.

${ }^{74}$ Article L. 611-8-1 (new), Commercial Code, inserted by Article 7, Ordinance of 2014.

${ }^{75}$ Article L. 611-14 (modified), Commercial Code, amended by Article 13, Ordinance of 2014.
} 
increasing the debtor's liability, in the event of an ad hoc mandate or conciliation being ordered. Similarly, any clause that imputes the creditor's legal costs to the debtor as a consequence of such court orders being made is also treated as void. ${ }^{76}$

\section{(b) Sauvegarde}

Including the article providing for the creation of the new sauvegarde financière accélérée, 34 of the 117 provisions are focused on the sauvegarde regime, illustrating continuing concerns about its operations and especially its take up rate. ${ }^{77}$ Nonetheless, the reforms here are seen as completing the improvement already initiated by the Ordinance of $2008 .{ }^{78}$ To start, the prevailing curial practice in sauvegarde proceedings especially of summoning the Treasury, usually to determine the debtor's tax position so as to elucidate the reality of a possible rescue,${ }^{79}$ has been generalised so that the courts can now hear any parties (outside the usual statutory list of participants) they deem useful. ${ }^{80}$ Covering concerns, however, about the authority of the court to make orders suo sponte opening proceedings, the provision allowing for the extension of sauvegarde proceedings to related entities now withdraws the court's capacity to do so, but permits the debtor to make any necessary application. ${ }^{81}$ Across the Commercial Code, the suo sponte facility has also been removed in the case of judicial rescue, liquidation, conversion from a failed conciliation to liquidation or opening of a post-conciliation liquidation. ${ }^{82}$ Authority has been transferred to the Public Prosecutor, who, being informed by the court of facts giving rise to the debtor qualifying for judicial rescue or liquidation, may make an application to that effect. ${ }^{83}$

\footnotetext{
${ }^{76}$ Article L. 611-16 (new), Commercial Code, inserted by Article 14, Ordinance of 2014.

77 Because the judicial rescue provisions refer back to the sauvegarde provisions, the latter procedure having originally been crafted on the model of judicial rescue, the changes and amendments will also have an effect on judicial rescue procedures.

78 Presidential Report, at paragraph I-4.

79 See commentary under Article L. 621-1 in A. Lienhard and P. Pisoni, Code des Procédures Collectives ( $11^{\text {th }}$ ed) (2013, Dalloz, Paris), at 82.

80 Article L. 621-1 (modified), Commercial Code, amended by Article 15, Ordinance of 2014, deletes the specific application in sauvegarde, while Article L. 662-3 (modified), Commercial Code, amended by Article 91, Ordinance of 2014, generalises the practice across all procedures.

${ }^{81}$ Article L. 621-2 (modified), Commercial Code, amended by Article 16, Ordinance of 2014. If the debtor subject to the original or extended proceedings exercises a profession subject to regulatory oversight, the relevant professional body must be heard prior to the order being made.

82 Articles L. 631-3, L. 640-3, L. 640-4 and L. 640-5 (all modified), Commercial Code, amended by Articles 49,58,59 and 60, Ordinance of 2014. Curiously, though, Article 20, Ordinance of 2014, which now authorises the debtor to make an application for conversion of sauvegarde proceedings to judicial rescue (amending Article L. 621-12 (modified), Commercial Code) has not apparently seen fit to limit the suo sponte facility that provision also mentions.

${ }^{83}$ Articles L. 631-3-1 and L. 640-3-1 (both new), Commercial Code, inserted by Articles 49 and 58, Ordinance of 2014, respectively. The texts also prevent the President of the Court, who normally receives the information, from sitting as part of the bench hearing the application.
} 
The roles of the debtor and Public Prosecutor in the nomination of the administrator and/or judicial nominee have been enhanced. The appointment by the court of more than one administrator/judicial nominee now can only take place if the court has duly asked the debtor for its opinion. Both the Public Prosecutor and debtor may designate more than one office-holder for appointment by the court, a change to the previous single nomination rule. Where the debtor's business is above a certain size, to be determined by decree, the Assurance de Garantie Sociale ("AGS") (Social Security Fund) must now be consulted on any appointments. Finally, those that are to be appointed, including any experts who are to carry out an inventory of the debtor's property, must notify the court as soon as possible of any factor that may justify their replacement by the court. ${ }^{84}$ The rights of the debtor and any creditor to seek the replacement of the administrator and judicial nominee, respectively, have been extended to cover any office-holder or expert appointed in proceedings. ${ }^{85}$ The right of the debtor to request the conversion of sauvegarde proceedings to judicial rescue, if a rescue plan has not been adopted by the relevant committees of creditors and/or bondholders, has now been extended to office-holders and the Public Prosecutor. ${ }^{86}$ Conversely, however, a partner or shareholder in a legal entity or company the subject of proceedings is now potentially liable to the rule that enables the judicial nominee to require the paying up of any unpaid capital to which he has subscribed. ${ }^{87}$

There are a number of provisions in this section dealing with creditors' rights. The first of these is a change to the monitor appointment provision which specifically recognise the rights of financial institutions and the AGS to be appointed, singling them out from the broad mass of creditors. ${ }^{88}$ The facility for the court to authorise the debtor to grant security or to settle or compromise any debts may not now be exercised unless the Public Prosecutor has been heard, thus addressing creditor protection concerns. ${ }^{89}$ The same applies where the administrator requires a contracting party to continue to fulfil its obligations. In such an instance, he is now required to ensure that he has the necessary funds to meet any liability that arises..$^{90}$ Conversely, a creditor risks losing the benefit of any priority in respect of postpetition debts, where sums have not been settled by the office-holder, if he does not tell the administrator of this fact. This rule does not apply if in fact the court has ruled on the admissibility of the debt. ${ }^{91}$ Where a creditor has brought

\footnotetext{
84 Article L. 621-4 (modified), Commercial Code, amended by Article 17, Ordinance of 2014.

85 Article L. 621-7 (modified), Commercial Code, amended by Article 18, Ordinance of 2014.

${ }^{86}$ Article L. 622-10 (modified), Commercial Code, amended by Article 22, Ordinance of 2014.

87 Article L. 622-20 (modified), Commercial Code, amended by Article 25, Ordinance of 2014.

This is reinforced by Article L. 624-20 (new), Commercial Code, inserted by Article 35, Ordinance of 2014, which states that a judgment opening proceedings has the immediate effect of requiring the payment up of any unpaid capital.

88 Article L. 621-10 (modified), Commercial Code, amended by Article 19, Ordinance of 2014. The monitors are present in the procedure to represent the general interest of creditors.

89 Article L. 622-7 (modified), Commercial Code, amended by Article 21, Ordinance of 2014.

90 Article L. 622-13 (modified), Commercial Code, amended by Article 23, Ordinance of 2014.

${ }^{91}$ Article L. 622-17 (modified), Commercial Code, amended by Article 24, Ordinance of 2014. Any debt thus notified also benefits from the exemption of having to re-prove if subsequent judicial rescue proceedings are opened, as would be the case if the sauvegarde procedure failed: Article L. 626-27 (modified), Commercial Code, amended by Article 42, Ordinance of
} 
proceedings against the debtor, the fact that a request for the opening of sauvegarde proceedings has been made must be notified to the creditor concerned by the debtor. ${ }^{92}$

Other provisions here deal with the process by which creditors prove debts. The first applies new periods for declaration, fixed at half the normal period, for creditors whose initial failure to prove has been excused by a court. Where debts have been proven by an agent acting on behalf of the creditor, the creditor may ratify the proof at any time up to the moment the court decides on its admissibility. Where the debtor has notified the existence of liabilities to the judicial nominee, this is taken to be the equivalent of a creditor's proof unless the creditor chooses to file a proof separately. Where the debtor is subject to an ongoing tax investigation, the judicial nominee cannot file a statement of the known debts (marking the end of his functions) until such point as the relevant statutory body has pronounced on the tax debt due. ${ }^{93}$ The proof, however made, is now to be deemed the equivalent of a claim at law and will interrupt the application of any limitation or prescription rule until the formal end of the procedure. ${ }^{94}$ If a question is raised by the judicial nominee in respect of a proof, the fact that a creditor fails to reply within the requisite period (30 (thirty) days) is not to be taken as acceptance of the views of the judicial nominee as to the lawfulness of the proof, ${ }^{95}$ although the creditor cannot dispute the ultimate decision of the judicial nominee as to its admission. ${ }^{96}$ Interest on any debt outstanding that will be the subject of a proof normally ceases to run at the point the order opening proceedings is given. Clarity is added in the 2014 reforms to stipulate that the interest, even if "capitalised" in this way, will no longer attract the payment of interest even if they remain outstanding for more than a year, as would otherwise be the case under Article 1154 of the Civil Code. ${ }^{97}$ The debtor is given an input into the admission of proofs by being permitted to make observations on the proofs received, in default of which he cannot later contest the decisions of the judicial nominee. ${ }^{98}$ The supervising judge is also given a power to deal in a summary manner with any objections to proofs he considers unfounded. ${ }^{99}$ The above provisions will serve to better clarify the process, which is central to the observation phase and which serves as a prelude to the formulation and adoption of the rescue plan.

2014. The same requirement to inform the officeholder applies in liquidation: Article L. 641-13 (modified), Commercial Code, amended by Article 68, Ordinance of 2014.

92 Article L. 622-22 (new paragraph), Commercial Code, amended by Article 26, Ordinance of 2014.

93 Article L. $622-24$ (modified), Commercial Code, amended by Article 27, Ordinance of 2014. The same applies in liquidation by virtue of Article L. 641-3 (modified), Commercial Code, amended by Article 64, Ordinance of 2014.

94 Article L. 622-25-1 (new), Commercial Code, inserted by Article 28, Ordinance of 2014. Where a creditor can prove that he is unaware of the debt, the limitation period to bring a petition to have his failure to prove excused runs from the moment he is deemed to have been aware of the existence of the debt: Article L. 622-26 (modified), Commercial Code, amended by Article 29, Ordinance of 2014.

95 As this can be challenged in any event before the court.

${ }^{96}$ Article L. 622-27 (modified), Commercial Code, amended by Article 30, Ordinance of 2014.

${ }_{97}$ Article L. 622-28 (modified), Commercial Code, amended by Article 31, Ordinance of 2014.

98 Article L. 624-1 (modified), Commercial Code, amended by Article 33, Ordinance of 2014.

${ }_{99}$ Article L. 624-2 (modified), Commercial Code, amended by Article 34, Ordinance of 2014. 
In fact, a great deal of focus is given in this section to the process by which the rescue plan is elaborated and a decision taken on its substance. Firstly, the definition of the plan and what it may contain has been rewritten. Although the rescue plan is still to contain the possibility of a cesser or addition or sale of the business, whether in whole or in part, some changes have intervened in respect of the possible identity of third parties in the case of a sale. This sees the interdiction on related parties acquiring the business or its assets within a period of 5 (five) years after the sale relaxed, except in the case of the debtor himself and the monitors. Sales are, nevertheless, still to be carried out by the judicial nominee in compliance with the general rules on sales in the context of liquidations. ${ }^{100}$ Where the rescue plan involves an increase in capital, partners and shareholders in legal entities or companies are able to set off their liabilities against any claims they may have that have been proven in proceedings. ${ }^{101}$ Where the partners or shareholders are required to approve any decision, whether one increasing the capital or changing any other provision of the articles, the court may determine that the first meeting summoned must have present that number of partners or shareholders representing at least half of the voting rights. Otherwise, and also in the event of any subsequent meeting being held, the quorum and voting requirements default to those in ordinary company law. ${ }^{102}$

The implementation of the plan and its success or failure also receive some attention in the reforms. Where a plan is implemented, the commissaire à l'exécution du plan (plan supervisor) has been given a right to come to court to propose a modification of the plan if the debtor's situation has improved and there is a likelihood of an extra benefit for creditors. ${ }^{103}$ In the case of default by the debtor in adhering to his obligations, if the plan supervisor should, for any reason, not be in a position to act, then any creditor may petition the court for the appointment of an ad hoc nominee to recover any sums due. ${ }^{104}$ Some attention is also given to the process by which creditors agree the plan. What has changed is firstly that the administrator must provide a report on any plan submitted to him or to the debtor by creditors, who have in any event the right to submit a proposal for a rescue plan. Creditors whose contracts with the debtor contain any clause regulating how the vote may be exercised or who benefit from either a guarantee or a subordination agreement must notify the administrator of this fact, whose decision on the value of the vote, taking into account the benefits accruing to the creditor, is notified to the creditor prior to

\footnotetext{
100 Article L. 626-1 (modified), Commercial Code, amended by Article 36, Ordinance of 2014.

101 Article L. 626-3 (modified), Commercial Code, amended by Article 37, Ordinance of 2014. This governs the position of the increase that is normally required in circumstances where the capital funds are less than half of the stated capital, as opposed to where the plan provides for a further injection of capital, for which Article L. 626-17, Commercial Code, already provides for a right of set-off.

${ }_{102}$ Article L. 626-16-1 (new), Commercial Code, inserted by Article 38, Ordinance of 2014.

${ }^{103}$ Article L. 626-26 (modified), Commercial Code, amended by Article 41, Ordinance of 2014.

${ }^{104}$ Article L. 626-27 (modified), Commercial Code, amended by Article 42, Ordinance of 2014. The reforms stipulate that the plan supervisor's task should not end before the payment of the last sums due under the plan, provided that this date is later than any such date that may have been agreed by the parties prior to the opening of proceedings: Article L. 626-31 (modified), Commercial Code, amended by Article 45, Ordinance of 2014.
} 
the meeting taking place. Any disagreement is to be submitted to the court for determination. ${ }^{105}$ In the event that a plan submitted by one of the creditors is approved by the creditors' meeting, then a new right given to the employees requires them to be informed through the requisite channels. ${ }^{106}$ The voting process for the "second bite" provisions, under which the failure by any of the creditors' or bondholders' committees to agree the plan simply results in the process resuming so that a further decision can be taken, is changed to ensure that the overall period within which a decision must be taken cannot exceed that of the observation period: normally 6 (six) months. This is to be determined by the court at the request of the administrator. ${ }^{107}$ Again, this seems to reflect the concern throughout these reforms that matters should be speeded up and a clear and swift exit from or transition between procedures should occur.

\section{(c) Judicial Rescue (Redressement Judiciare)}

As the section dealing with judicial rescue refers back in many instances to those governing sauvegarde, actual amendments to this section are not as extensive as elsewhere. However, they include the provision determining when the debtor entered into cessation de paiements (cessation of payments, i.e. became insolvent), which is now to take place with the debtor's views being solicited prior to the court's decision. ${ }^{108}$ Views are also sought from the debtor and any creditors for the appointment of the administrator and judicial nominee, respectively. ${ }^{109}$ As in the case of sauvegarde, the administrator has to ensure that he has the necessary funds to pay for services or goods received under continuing contracts, unless he is able to secure any grace period for payment. ${ }^{110}$ However, unlike sauvegarde, where the administrator may be given authority by the court to summon the necessary shareholder/partner meetings to vote on any increase in capital that may be required, he is expected in judicial rescue to go to court for the appointment of a judicial nominee where there appears to be opposition from any party who may be called upon to contribute to the increase. ${ }^{111}$

The major focus in these limited selection of amendments to judicial rescue is on the development of the rescue plan and any alternatives, although the

105 Article L. 626-30-2 (modified), Commercial Code, amended by Article 43, Ordinance of 2014. For bondholders, the value of their vote, if a meeting of their class is required, is determined without reference to the value of any accessory security given by the debtor by which they may benefit. Otherwise, the voting rules for creditors' committees are to apply to bondholders' committees: Article L. 626-32 (modified), Commercial Code, amended by Article 46, Ordinance of 2014.

106 Article L. 626-30-3 (new), Commercial Code, inserted by Article 44, Ordinance of 2014.

107 Article L. 626-34 (modified), Commercial Code, amended by Article 47, Ordinance of 2014.

108 Article L. 631-8 (modified), Commercial Code, amended by Article 50, Ordinance of 2014. The same provision also stipulates that the court's authority to backdate the effective date of insolvency is not affected by the opening of a sauvegarde financière.

109 Article L. 631-9 (modified), Commercial Code, amended by Article 51, Ordinance of 2014. The right of the Public Prosecutor to nominate the office-holders has apparently been removed.

110 Article L. 631-14 (new paragraph), Commercial Code, amended by Article 53, Ordinance of 2014.

${ }^{111}$ Article L. 631-9-1 (new), Commercial Code, inserted by Article 52, Ordinance of 2014. 
basic responsibility for developing the plan remains with the administrator, assisted by the debtor, while the decision on the plan continues to fall within the province of the creditors' committees, to whom the plan is presented by the administrator. Moreover, the general rules on the rescue plan in sauvegarde will continue to apply, as amended by the Ordinance of 2014 . There is a change, nonetheless, in the application of the sauvegarde rules in that the exemptions from the list of parties prevented from bidding for the assets do not apply to asset disposals in judicial rescue. The rules also applicable to rescue plans in sauvegarde involving the workforce do not apply here, as the remaining changes to the article deal with a new procedure for any necessary redundancies as well as special provisions for a rescue of employment where possible. Generally, the process will be under the supervision of the court and must take place in accordance with the terms of the Employment Code.

Further changes include the situation where a third party (other than a partner or shareholder) agrees to be bound to implement the plan, usually in return for capital rights. In this case, the plan that has been voted on by the creditors' committees and, if necessary, the bondholders' committee will also need to be submitted to the general meeting of partners/shareholders and be approved by a resolution being passed. ${ }^{112}$ The facility for the court to order a total or partial sale of the business, formerly dependent on the debtor's inability to continue performing his obligations under the plan, are now made dependent instead on the plan appearing "manifestement insusceptible" (manifestly incapable) of ensuring the rescue of the business. ${ }^{113}$ Finally, dealing with the rules on vulnerable transactions, which apply to judicial rescue, but not to sauvegarde, the reforms add the decision by an individual entrepreneur to separate a business pool of assets from a personal pool to the list of acts that are void if carried out after the date the debtor became insolvent and may also be rendered void if performed within the six months prior to that moment. ${ }^{114}$

\section{(d) Liquidation and Simplified Liquidation}

The amendments in this section are almost as extensive as those directed at the sauvegarde procedure and are described by the Parliamentary Report as ranging from those simply "correcting impreciseness", via those that are "more marked", to those that are "more innovative". 115 The reforms appear concerned with making adjustments to the rights and liabilities of participants, including by extending to instances of liquidation the debtor's duty found in other procedures to assist in the completion of the asset inventory and to provide the office-holder with a list of contracts as well as assets and liabilities. Conversely, the debtor now receives the benefit of a stipulation that the costs of living for any debtor who is an individual will be paid in priority to all other debts, where these costs fall due after proceedings are opened. ${ }^{116}$ The opening of a liquidation procedure in respect of a debtor whose business

\footnotetext{
112 Article L. 631-19 (modified), Commercial Code, amended by Article 54, Ordinance of 2014. ${ }_{113}$ Article L. 631-22 (modified), Commercial Code, amended by Article 55, Ordinance of 2014.

114 Article L. 632-1 (modified), Commercial Code, amended by Article 56, Ordinance of 2014.

115 Parliamentary Report, at paragraph III-3.

${ }^{116}$ Article L. 641-13 (modified), Commercial Code, amended by Article 68, Ordinance of 2014.
} 
is greater than a threshold to be determined will now result in the AGS being invited to give its views on the nomination of a liquidator. ${ }^{117}$ Where a judicial rescue or sauvegarde procedure is being converted to a liquidation, which would normally result in the judicial nominee being appointed liquidator, the AGS now receives the right to request that a different liquidator be appointed. ${ }^{118}$ The AGS will also be given the right to be consulted prior to redundancies being carried out in the context of any proposed sale of all or part of the business. ${ }^{119}$

Further alterations to the rights and duties of participants in the process result in the Public Prosecutor now being able to propose the nomination of an administrator by the court to second the liquidator in the running of the business where the size of the business is above a specified threshold. ${ }^{120}$ The liquidator has now been given the power to agree, with the consent of the administrator (if one is appointed), to the restoration of property to a third party subject to any claim for restitution or recovery. If the two office-holders are not in agreement or either (or both) of them wishes to bring a dispute as to the merits of the claim, then the issue is brought for determination before the court with the debtor additionally being summoned to give his views. ${ }^{121}$ Creditors, however, are subject to a new requirement to restore to the estate any sums received in breach of the pari passu rule or that result from a mistake as to the order of priority. ${ }^{122}$ More generally, the prohibition on related parties and any participants in the process acquiring assets or the business has been clarified. The basic principle is that assets may not be acquired by related parties and any participants in the process except as authorised by the court. This exemption now applies to the business, immoveables, goods sold at auction and goods of a personal nature or those used in an agricultural business. The benefit of the exemption, however, still does not extend to the debtor or to the monitors. ${ }^{123}$

Speeding up the procedure and reducing costs also seem to be features of the amendments, for example the new injunction that the supervisory judge must rule as soon as practicable on the admissibility of any request made to the court for the replacement of the liquidator and the option for the liquidator in the simplified liquidation procedure to carry out the inventory. ${ }^{124}$ In the latter case, although the liquidator may take inventory, one of the experts commonly appointed in liquidations to do so will carry out the valuation of the assets concerned. ${ }^{125}$ Similarly, a cap is put on the time within which ascertainment of

\footnotetext{
117 Article L. 641-1 (modified), Commercial Code, amended by Article 61, Ordinance of 2014.

$118 \mathrm{Idem}$. The option is also given for the employees' representative elected by the workers, in the absence of a Comité d'entreprise (Works Council) or Délégué(s) du personnel (Workers' Representative(s), to exercise the functions devolved to these institutions.

119 Article L. 642-5 (modified), Commercial Code, amended by Article 71, Ordinance of 2014.

120 Article L. 641-10 (modified), Commercial Code, amended by Article 67, Ordinance of 2014.

${ }^{121}$ Article L. 641-14-1 (new), Commercial Code, inserted by Article 69, Ordinance of 2014.

122 Article L. 643-7-1 (new), Commercial Code, inserted by Article 76, Ordinance of 2014.

${ }^{123}$ Article L. 642-20 (modified), Commercial Code, amended by Article 75, Ordinance of 2014.

124 Articles L. 641-1-1 and L. 641-2 (modified), Commercial Code, amended by Articles 62 and 63, Ordinance of 2014. For ordinary liquidation procedures, the court will normally appoint an expert (auctioneer, bailiff, notary or commercial agent) to take inventory and value the assets concerned.

${ }^{125}$ Article L. 644-1-1 (new), Commercial Code, inserted by Article 81, Ordinance of 2014.
} 
proofs takes place when a simplified liquidation procedure is converted to a normal liquidation, when 6 (six) months is the authorised maximum for this to take place. Furthermore, a very brief limit (12 (twelve) days) is imposed on the submission of a report by the Works' Council in respect of redundancies the liquidator proposes to carry out, either immediately or following a resumption of some activity for a determined period. ${ }^{126}$ The singular reform here is the new upper limit on simplified liquidation proceedings, which are brought down from twelve (12 months) down to 4 (four) months. ${ }^{127}$ By contrast, however, the period for the sale of assets in a simplified liquidation has been extended from 3 (three) to 4 (four) months, ${ }^{128}$ perhaps to avoid issues arising as to the resumption of proceedings in the event of the discovery that assets remain unsold and the attendant costs, not to mention the impact on the debtor's discharge. Otherwise, the adjustments here in terms of time seem to provide more emphasis on these procedures being geared towards restoring assets and value as quickly as possible to interested parties, particularly the creditors.

\section{(e) Miscellaneous Amendments}

A few miscellaneous changes have also taken place to the sanctions provisions and curial procedure. The option for the court to declare the personal insolvency of directors, managers or representatives of corporate directors, has been extended to include where any of these persons knowingly makes a false proof of debt on behalf of a creditor. ${ }^{129}$ The alternative of a disqualification from being involved in management now also applies to the situation where any of the above parties knowingly fails to inform a creditor in litigation against the debtor of an application for sauvegarde proceedings in respect of the debtor. ${ }^{130}$ Apart from instances of the suo sponte facility now being abolished, ${ }^{131}$ there is now a generalised rule that the supervisory judge may not take part in bench formations in the court that appointed him, nor participate in any of its discussions. ${ }^{132} \mathrm{~A}$ particular innovation here is the new provisions that governs the situation where a number of courts are involved in hearings covering companies or entities belonging to the same group. A new option is given to appoint the same administrator and judicial nominee for all of the companies and legal entities concerned and for them to undertake the task of coordinating procedures subject to rules to be published by decree. ${ }^{133}$

\footnotetext{
${ }^{126}$ Article L. 641-4 (modified), Commercial Code, amended by Article 65, Ordinance of 2014. 127 Article L. 644-5 (modified), Commercial Code, amended by Article 84, Ordinance of 2014. 128 Article L. 644-2 (modified), Commercial Code, amended by Article 82, Ordinance of 2014. The only asset disposal requiring the concurrence of the debtor is one resulting from an inheritance received by the debtor following the opening of proceedings: Article 641-9 (new paragraph), Commercial Code, amended by Article 66, Ordinance of 2014. The debtor must also concur in the conversion of jointly held property to property in common.

129 Article L. 653-5 (modified), Commercial Code, amended by Article 87, Ordinance of 2014.

130 Article L. 653-8 (modified), Commercial Code, amended by Article 88, Ordinance of 2014. See above note 92 for the new duty to inform.

131 See above footnote 82.

132 Article L. 662-7 (new), Commercial Code, inserted by Article 92, Ordinance of 2014. Article 86 , Ordinance of 2014 , removes two specific instances where this prohibition previously existed in the case of sanctions involving the debtor.

${ }^{133}$ Article L. 662-8 (new), Commercial Code, inserted by Article 93, Ordinance of 2014.
} 


\section{Summary}

The amendments resulting from the Ordinance of 2014 must be sited in the context of planned further work, not just that resulting from the implementation decree and other likely changes to harmonise the articulation of the texts with each other, but also to complete other reforms, for which authority was not forthcoming in the Law of 2014, but which might soon come. Other likely changes include planned alterations to the status of insolvency office-holders and commercial courts and also work to take into account amendments to the European Insolvency Regulation that are ongoing. ${ }^{134}$ The impact of the Commission Recommendation of March 2014 seeking to improve the performance of national insolvency regimes for SMEs also needs to be assessed. ${ }^{135}$ For some, the upshot is to leave France's insolvency law regime in a state of some "legal [in]stability" with the prospect of more "opportunistic" legislation. ${ }^{136}$ This idea of opportunism is reflected in the view that the idea of reform preceded that of the contents of the same: "the principle of reform being a given, it [only] remained to determine what needed reforming". ${ }^{137}$ Despite these views, many aspects of the reforms have met with the definite approval of commentators. Labels such as "innovative, often practical", 138 "more performing tools, better legal security and renewed equilibrium" 139 have been attached to the reform text and to the changes it made.

Overall, the impression is that some thought has been given to improving matters, albeit on a procedural level, without fundamentally altering the basis on which French insolvency law functions. However, it is also noteworthy that insolvency office-holders have had little time to adjust, the reforms coming into force on 1 July 2014. ${ }^{140}$ This speed, which was also evident in previous reforms must make practice quite challenging in an environment where the rules change often, again raising the spectre of legal instability alluded to earlier. Given the duration of many procedures, a related concern is that the office-holder may find himself applying different sets of rules to different cases, depending on when proceedings were instituted, which is not ideal. In this light, the question may well be asked as to what will happen in the future? Will the reforms be left to bed in, as those of 2005 were not (with those of 2008 only in operation a few years before these changes)? Will the experience of the reformed text raise further issues that will militate for yet more reforms? The answer to the last, in view of the apparent endurance of France's reform process, is a qualified yes. At least there is some consciousness of this and the need to be prepared. For one commentator, insolvency law "requires great vigilance on the part of observers, practitioners and the legislator". With this in mind, the Minister of Justice is apparently

\footnotetext{
134 Rossi et al., above note 45, at 2. Pétel, above note 19, at paragraph 1 , also refers to the difficulties of reforming the operations of the Commercial Courts, which is to be left to a future text so as not to "raise polemics".

135 Roussel Galle, above note 62, at 34.

136 Rossi et al., above note 45, at 2.

137 Pétel, above note 19, at paragraph 2.

138 Le Corre, above note 19, at 751 (paragraph 73).

139 Roussel Galle, above note 68, at 351.

140 Article 116, Ordinance of 2014.
} 
ensuring that the necessary analytical tools are put into place rapidly so as to chart the progress of these reforms and their impact on French businesses. ${ }^{141}$ In long run, this can only be a positive improvement in what seems, over the years, to have been a constant, but somewhat vain, attempt to find the right solution.

15 August 2014 (revised 30 August 2014)

${ }^{141}$ Rossi et al., above note 45 , at 3. 